Febri Choiru Rozikin; Moses Glorino Rumambo Pandin

Faculty of Humanities, Airlangga University

Campus B, Jl. Dharmawangsa Dalam, Airlangga, Kec. Gubeng, Surabaya, East Java 60286

febri.choiru.rozikin-2020@ fib.unair.ac.id moses.glorino@ fib.unair.ac.id

\title{
BOOK REVIEW: \\ "MEMORI GENOSIDA: MELIHAT KEKERASAN KOLEKTIF MASA LALU DALAM PERSPEKTIF HOLOCAUST" (GENOCIDE MEMORY: SEEING PAST COLLECTIVE VIOLENCE IN HOLOCAUST PERSPECTIVE)
}

Author: DR. FX. Baskara T. Wardaya, SJ; Jakarta City; Year of Issue: 2021; ISBN: 978-602-06-4835-4 (PDF); Number of pages: 264 Pages

The book with the title "Memori Genosida: Melihat Kekerasan Kolektif Masa Lalu Dalam Prespektif Holocaust" is written to remind youth generations to take lessons from the events of the Holocaust, not to repeat itself back. The events of the Holocaust are very imprint in the memory, where approximately 6 million lives of humans disappear drain the drain. As a historian, the writer certainly would like to remind back to us about how the cruelty and brutality of group dominance (NAZI ) against a group of others ( Jewish ) are massive.

Based on the book's purpose was written and the style of language used, the book targets youth, especially university students, and the public community interested in the discussion of history. The book can also be read for the activists of human rights in Indonesia because of load cases slaughter 65 ' and attached proof of evidence that there is.

Statement for the sake of the question that appears to say that collective violence does not occur suddenly but begins in various attitudes discrimination, segregation and actions alienate others. Holocaust as an event of collective violence future is a proof of actual situation, how a series of attitudes violent Arians against the Jews in the span of a few years only, can become an event of genocide. The book can also predict how modernization current based on the perspective of the Holocaust, whether ongoing good or even worse in the future.

Various things loaded from the book also have many experts' perspectives, raising multiple questions recently. So it needs to do a review on the book this. because there are none of the readers, do review this book, the possibility of going on misunderstanding the message delivered from the book.

The book "Memori Genosida: Melihat Kekerasan Kolektif Masa Lalu dalam Prespektif Holocaust" is discuss about the events of the Holocaust. From the title implies, we showed flow about events of the Holocaust from the start occurrence to their aftermath. Then from the circumstances, the authors conclude in general about what causes the events of the Holocaust. As a reader, of course, respect is very appropriate to the content of which is expected. In this book, we know the causes of the beginning event and conclude what is discussed.

There is a variety of information that is new which derived from the book is as a new reality about the Holocaust. Holocaust, an event of crimes of humanity, not as well as necessarily occurs in arriving arrive. Instead, it is the fruit of various attitudes, discrimination, exclusion, and segregation performed by the Arians to the Jewish. People Jew gets treated sort also supported by the state (Nazi). The state considers that the goals will be easily achieved if there are no obstacles. Here the Jewish nation is seen as an obstacle to the nation's goals so that various acts of violence are always directed at them. Until the end, bear on an event that is known as the Holocaust.

Then also visible reality just that hatred against the Jews has come from the people of Germany. Still, there is also some Austrian community who commit crimes similar to the Jewish. But on the other hand, some non-Jews help Jewish from those crimes.

As a reader, we will be wondering, is it true that the Holocaust only caused by the cruelty of the Nazis, or are they just entities that carry out their functions? Of course, readers need to look for sources other than to complete the terms of this. Fortunately, this book is also included various sources from another expert.

In this book, something that is not aware is to invite us (readers) to be critical in assessing each situation up again with a problem of violence in today's and the future, how behavior towards others, and our movements to response victims of violence. 
Some evidence indicating the book's cover story of the offender's history of the Holocaust, either that of the perpetrator or the victim, is also an attachment of photos, photographs, and the author's data as a reinforcement of the revelation of the contents of the book. Besides that, the evidence of the source of reading another of the book becomes an important part.

The various sources that exist are certainly not sources playing games. The author himself wrote this book after attending a series of seminars and workshops, one of which is the ICEH (International Conference on Educational Scientific and Cultural Organization) conference in Washington DC, United States. The author and participants attended many countries.

The book shows some evidence in chapter 1, where the author discusses the Holocaust based on Zygmunt Bauman's thoughts. Bauman's three books were sources, namely, Modernity and the Holocaust, Modernity, Abvicalence, and Liquid modernity. Then also the chapter into two, there is a book Bauman are entitled Postmodernity and its Discontents. Photos of photos are also attached documents original obtained by the authors of the museum.

The preparation of the book using a style of language that is easily understandable. The author knows how to terms and names are challenging to understand always in the quotation's sign. Pages are totaling 264 pages, not too thick and not too thin. Each chapter in the book is always given a list of references, so it is easier for the reader to know the source of reference used in every discussion. Following the purpose of books is like ignite back sense of curious readers in particular subjects who do not want to bother to read books thick overly.

Another thing that the author should note is the author seems deliberate to create a gap in every question. At the end of a chapter, the writer always gives questions to the readers to be discussed or pondered over so that the author has written some things that the reader should consider.

The advantage of this book is the wide range of views of the experts listed by the authors that enrich the reader's knowledge. The number of reading sources that used writer, proof evidence of concrete as an attachment interview, and evidence of photos make the book more interesting to read. And do not forget at every naming and term, writers always wear quotation marks to facilitate the reader.

Weaknesses are apparent from the book is in part a chronology from each chapter, which is not so neat. Although the book is not intended to discuss the Holocaust in particular, a leap year every chapter and paragraph is quite difficult for the reader to understand the flow of events of the Holocaust.

In my opinion, for readers, this book is necessary to read many references on discussion materials, especially on the flow of Holocaust events. The book is not purposed to explain Holocaust in chronological order but instead describes various new facts of the events. To understand the contents are also needed references from other sources. My advice to the author is to give attention to chronological events in the book that appear not to be regular. Preferably it was addressed to facilitate the reader to understand the flow of events.

Febri Choiru Rozikin; Moses Glorino Rumambo pandin Airlangga University

\section{REFERENCES}

1. Baskara T. Wardaya. Memori Genosida: Melihat Kekerasan Kolektif Masa Lalu dalam Perspektif Holocaust. Pertama. Jakarta: PT. Gramedia Pustaka Utama; 2021. 264 p.

\section{AUTHOR SHORT-BIODATA}

Dr. FX. Baskara T. Wardaya, SJ, is a lecturer from the University of Santa Dharma since the year 2002 he received the title of bachelor's degree from Universitas Sanata Dharma in Yogyakarta and Sekolah Tinggi Filsafat Driyarkara in Jakarta. Then obtained a degree Doctorate and Masters in the fields of history from Marquette University, Milwaukee, Wisconsin, United States. Apart from being a lecturer, Baskara also serves as the Head of PUSDEMA Sanata Dharma University. Baskara has written many books that have been publishing. Examples such as, Menyusuri Jejak Suci (2020), Keeping Hope (2017), Bertemu Matari (2014), etc. 